NEUROLOGICAL PICTURE

\title{
Sunflower cataract in Wilson's disease
}

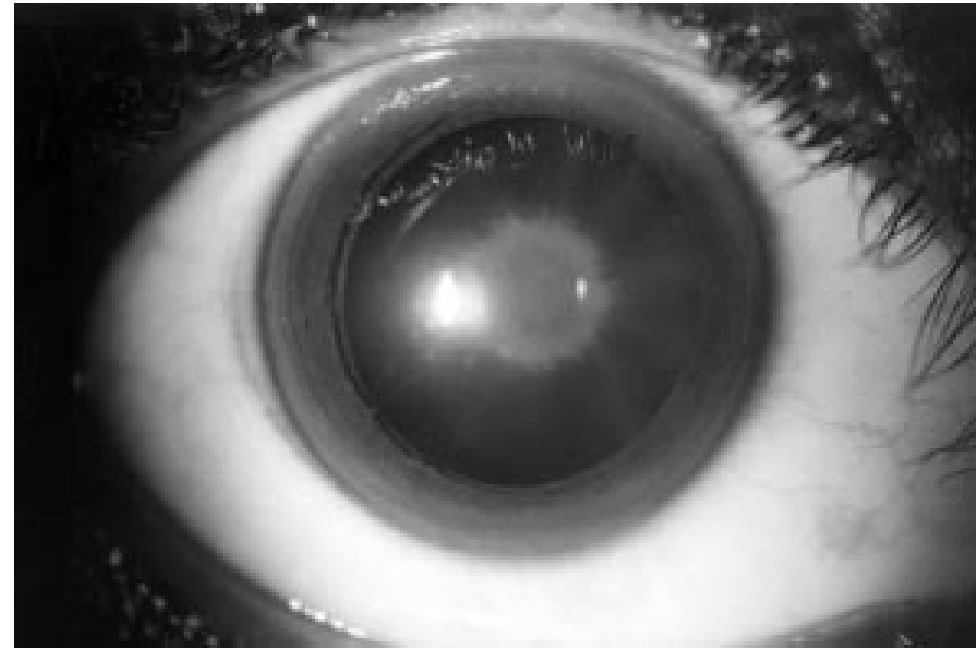

Figure 1 Right eye showing Keyser-Fleischer ring and sunflower cataract.

Wilson's disease is an autosomal recessive, multisystem disorder due to impaired hepatic excretion of copper. There is excessive accumulation of copper in the CNS, liver, kidneys, cornea, and other organs. ${ }^{1}$ This accumulating copper leads primarily to damage of the liver and brain. Predominant presentation includes dystonias, tremor, dysphasia, dysarthria, gait and limb ataxia, and neuropsychiatric manifestations. The Kayser-Fleischer ring, a brownish coloration of the outer margin of the cornea in Descemet's membrane, is diagnostic of Wilson's disease, which regresses on treatment with metal chelating drugs. ${ }^{2} 3$ Sunflower cataract was first described in Wilson's disease by Seimerling and Oloff. ${ }^{4}$ We report a case with classic sunflower cataract with bilateral putaminal hypodensities on CT and hyperintense signal on T2 weighted image on MRI.

This 10 year old girl had progressive visual loss for the past 2.5 years and recurrent jaundice for the past 2 years. She had had progressive difficulty in writing for 2 months with tremors and abnormal posturing of her right arm. She also had dysphasia and dysarthria of the same

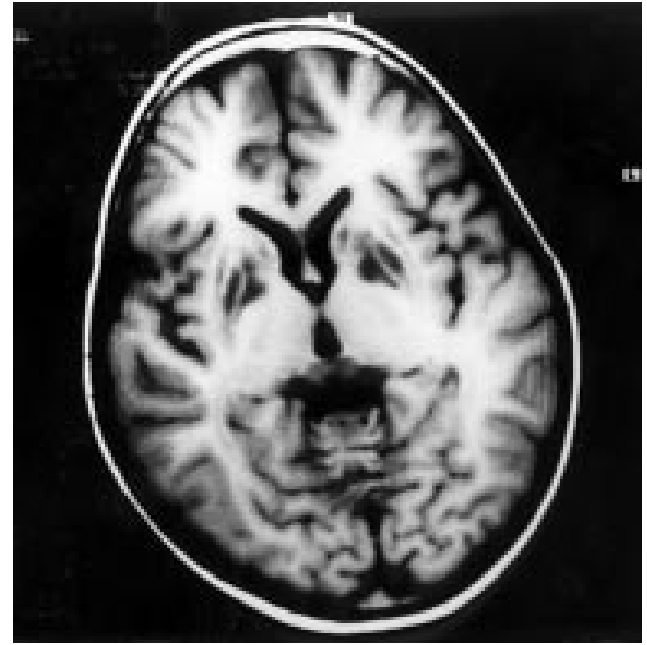

Figure 2 Brain MRI showing a bilateral hypointense signal in the putamen on T1 weighted image.

duration and was practically mute, but with preserved comprehension. On examination, she had bilateral sunflower cataract and a Kayser-Fleischer ring (fig 1). Her serum copper concentration was $180 \mu \mathrm{g} / \mathrm{dl}$ (normal $14-140 \mu \mathrm{g} / \mathrm{dl}$ ) and her ceruloplasmin concentration was $1.4 \mathrm{mg} / \mathrm{dl}$ (normal $2-17 \mathrm{mg} / \mathrm{dl}$ ). Brain MRI showed a hyperintense signal bilaterally in the basal ganglia on T2 weighted image (fig 2).

V GOYAL $M$ TRIPATHI

Department of Neurology, C N Centre, All India Institute of Medical Sciences, New Delhi 110029, India

Correspondence to: Dr M Tripathi

manjan@mednot.emet.in

1 Cumings JN. Trace elements in brain and Wilson's disease. f Clin Pathol 1968;21:1-7.

2 Finelli PF. The Kayser-Fleischer ring: hepatolenticular degeneration (Wilson's disease). Neurol 1995;45:1261-2.

3 Johnson RD, Campell RJ. Wilson's disease: electron microscopy, $x$ ray energy spectroscopic and atomic absorption spectroscopic studies of corneal copper deposition and distribution. Lab Invast 1982;46:546-69.

4 Siemering E, Oloff H. Pseudoskierose (WestphalStrumpell) mit cornealring (Kayser-Fleischer) and doppelStrumpell) mit cornealring (Kayser-Fleischer) and doppel-
seitiger Scheinkatarakt, die nur ber seiticher Beleuchtung seitiger Scheinkatarakt, die nur ber seiticher Beleuchtung
sichtbar ist und die der noch Verletzune durch Kupfersplitter entstehenden Katarakt ahnlich ist. Kiln Wochenschr ter entstehenden
1922;1:1087-9. 